\title{
Do Peer Influence Corporate Firms? Evidence from Working Capital Management Practices
}

\author{
Umar Farooq 1 \\ School of Finance and Economics, Xian Jiaotong University, Shanxi, China \\ Jaleel Ahmed \\ Department of Management Sciences, Capital University of Science and Technology, \\ Islamabad
}

\begin{abstract}
Working capital management requires a careful attention by the corporate managers because it plays an important role in corporate stability. Social belongingness of managers induced them to learn from their society, colleagues and from overall industrial movement. They also learn from their peers which have more strategical efficiency. In line with these arguments, the objective of current study is to explores the peer influence on corporate working capital management practices. To making analysis, ten-years data (2009-2018) of non-financial publicly listed firms at PSX were collected and cash conversion cycle (CCC) uses as proxy variable of working capital management (WCM). To estimate the regression, an econometric technique named Generalized Method of Moments (GMM) was used. The empirical findings suggest the significant impact of peer WCM on corporate WCM. It also suggests the significant impact of other variables that determine the WCM. This study recommends social learning policy to corporate managers. They can learn from their peers to manage the working capital. Most previous studies discuss the peer influence on investment decision, corporate cash holding and financing policy etc., but no study explores such relationship specifically in Pakistani non-financial sector data set.
\end{abstract}

Key Words: Working Capital Management, Peer Influence, Cash Conversion Cycle, Macro-Economic Factors, Generalized Method of Moments (GMM)

\section{JEL Classification: G31: G41}

\footnotetext{
${ }^{1}$ Corresponding author: umerrana246@gmail.com
} 


\section{Introduction}

The efficient management of working capital which indirectly refers to the management of both current assets and current liability determines the corporate profitability. Due to complex business environment and insufficient business information, the management of working capital ignore at some level. This factor induces the corporate firms to more volatile position which in turn deplete the firm profitability (Ganesan, 2007). The corporate managers try to maximize their working capital efficiency by utilization of different tools such as good governance (Gill \& Biger, 2013), precautionary and transaction motives (Kim, Kim, \& Woods, 2011), holding the more cash (Afza \& Adnan, 2007) and sale growth (Kwenda, 2014). Despite of these factors, mimicking behavior paves way of corporate decision making (Leary \& Roberts, 2014) and determines the sectoral base future business trend. By assessing this trend, the main purpose of this study is to analyzes the influence of peers on corporate working capital management (WCM) practices.

Working capital management is a strategical decision which comprises of management of receivables, inventory and payables collectively known as cash conversion cycle. Basically, the whole discussion on corporate finance is in three folds i.e. capital structure, capital budgeting and management of working capital. The decisions on capital structure and capital budgeting relates to long term financing and managing the long-term investment relatively while management of working capital is a short-term decision relating to financing and investment. It includes the management of both shortterm financing (payables) and short-term investment (investment in inventory). Therefore, inefficient management of working capital can directly affect the company liquidity and smooth running of business. While proper management of inventory which is fundamental part of working capital has significant impact on firm profitability (Farooq, 2019). Specifically, it's more important for manufacturing companies because their more than half of assets comprises of current assets (Sharma \& Kumar, 2011). Even a company has increasing profitability, but improper management of working capital may lead to bankruptcy due to excessive current assets and current liability which enhance the business volatility (Rehman \& Nasir, 2007). Therefore, proper 
management of working capital is a fundamental part of business decisions as it creates the shareholder wealth.

Herding or mimicking behavior refers to attitude of firms or managers in which they copy their peer firms. It's common for corporate managers to interact with their peer firms to organize the business strategies. The corporate managers continuously adhered with their peer's business movement to ensure the organizational stability. Moreover, corporate herding behavior mitigates the substantial business risks in variety of business decisions i.e. merger and acquisitions (Bizjak et al., 2009), tax avoidance (Li et al., 2014), financial policy (Leary, 2014), and investment decision (Chen \& Hui, 2017). The growing literature on corporate mimicking behavior intensifies to more empirical studies those may argued such other strategic linkages between corporate and peer firms. A firm can't perform its business dealings without interacting with their peers specifically in same industry. It must design their business model which effectively incorporates the sectoral effect and exhibits significant level of industrial prevalence. Mutual co-operations can turn into financial benefits both for peer and corporate firms (Liu and Chen, 2012).

The concept of working capital management (WCM) has grabbed the major intention of corporate managers since after the financial depression in 2008. The firms carefully manage their working capital because it affects the corporate stability and profitability (Gill et al, 2010; Ukaegbu, 2014). Before this event, the area of working capital management was conservative both for researchers and corporate managers due to routine checking of activities i.e. inventory handling and trade credit decision which alternatively connected with working capital management practices. Another factor behind low intentions was the consideration of WCM for firm financial performance deemed to be low (Singh \& Kumar, 2014). But some specific circumstances i.e. financial depression, competitive business environment, globalization and more focus on total quality management (TQM) enhance the research focus and pushes the corporate manager's effort towards WCM.

The link between the mimicking behavior and working capital management can be developed from the findings of previous studies. The study of Leary and Roberts (2014) 
suggested the significant influence of peer firm on corporate financial policies. The working capital management is also a important part of firm financial policy. The corporate firms may arrange their financing arrangements in accordance with working capital management (Zubairi, 2011). Morover, another argument was built by Anwar \& Akhtar (2018) in which they have documented the peer effect in terms of corporate investment. They have specified the mimicking attitude of Pakistani non-financial sector firms and found the significant relationship between corporate and peer firms. The research has also argued that the working capital management is a part of firms active investment (Kieschnick, 2013). These findings enhance the intention to investigate the mimicking behavior of corporate firms in term of working capital management practices.

Strategically, corporate firms indulged in herding for two reasons. They herd their peers to exclude their competitors from industry. Corporate firms copied the successful strategies and promote the unfair industrial competition for their colleague firms even in same industrial group. Likewise, other motives are to create the stringent hurdles for companion firms specifically in financing. It also compels them to acquire more debt which results in bankruptcy (Chevalier, 1996). But in contrast, other reason of mimicking is learning which is completely different from previous one. In doing so, corporate managers follow their peer firms to learn about rational decision making. They learn about financing decision, investment decision, and cash holding etc. This motive emphasizes more on use of useful information for stabilizing the business activities instead of rivalry or compression of others. In this study, the mimicking behavior analyzes with respect to learning attitude. Corporate firms may learn from their peers to manage their working capital. But sometimes more focus on mimicking can leave some non-beneficial effects. Behavioral model advocates that mimicking attitude driven from irrational forecasting by managers results biased decisions. For example, a manager thinks about perfect anticipation of future due to overconfidence in contrast he can. This biasness may lead to wrong managerial decision. Therefore, corporate managers should wisely decide the mimicking decision. 
This study explores the relationship between the peer and corporate firm's working capital management practices. The focus of study is to highlights the role of herding behavior in working capital management. It also identifies the other firm specific and country specific determinants which have critical role in determining the working capital management. Cash conversion cycle (CCC) is used to measure the working capital management. Other determinants which were suggested by the previous studies are leverage, profitability and firm size. It also includes the macro-economic variables such as gross domestic product (GDP), inflation and financial sector development. These were included to capture the country level effect on business decision. The findings of study show the significant relationship between corporate and peer firm working capital management practices. The findings are expected to enhance corporate manager. s decision making efficiency and will help in managing the working capital specifically in Pakistan. It further strengthens the views of financial economist who favored the role of macro-economic condition of a country in financial decision of corporations.

The rest of paper follows the pattern as: section 2 consists of detailed literature review, section 3 discusses the data and methodology, section 4 carries the discussion on results, and section 5 conclude the whole discussion of paper. It also describes the limitation and future directions. The referencess detail is given at the end of paper.

\section{Review of Literature}

\subsection{Working Capital Management}

The management of working capital is a managerial level activity in which managers involved in managing the size and overall effectiveness of working capital (Kaur, 2010). The working capital categorized into two components i.e. gross working capital which employs the current assets and net working capital which is residual amount after deducting the current liability from current assets. The main objective of working capital management is to manage the current assets and current liabilities (Padachi, 2006) which incorporated by cash conversion cycle (CCC) (Deelof, 2003). The CCC is systematic measurement which extensively used as proxy of working capital 
management in previous studies and directly achieved the goal of management of current assets and current liability (Ganesan, 2007; Enqvist et. al., 2014; Mazlan \& Leng, 2018). The CCC expresses the time span between investments in inventory to cash inflow from sales. The efficient management of working capital indices the quick recovery of funds pronounced as short CCC. A short CCC is always preferred because it corroborates the stability and profitability of firms (Enqvist et al., 2014). The whole working capital management discussion can be summed into short CCC. In literature, number of studies stressed upon the importance of working capital management and its effect on firm profitability (Deelof, 2003; Afza \& Nazir, 2008; Charitou et al., 2010; Knauer, 2013; Mazlan , 2018). The high degree of literature stimulates to analyze the working capital management practices in relevance of peer influence.

\subsection{Peer Effect}

Peer effect deemed to be an influential state when corporate firms indebted to their peer firms of same industry in variety of business decisions. But this obliging behavior is totally different from common or correlated effect. In peer effect, the corporate firms deliberately indulged in mimicking their peer firm's policies (Grennan, 2019). The recent findings of literature have exhibit that managerial level decision influence due to their social involvement. The managers learn from their social network and their decisions influence due to this network besides from experience and innate beliefs (Shue, 2013). The study arranged by Graham and Harvey (2001) has depicted the worth of available information in different financial decisions specifically in risky environment. They have augmented that the firms rely more on their peer firms when outcomes are highly uncertain. This view has also strengthened by other corporate level studies (Maquieira, 2012). The corporate firms deploy their decision in line with their peer firms due to certain motives i.e. unity of successful strategies, eradication of ambiguity and termination of unfavorable market competition (Leary, 2014). Furthermore, peer influence is necessary due to undeniable social belongingness of managers with each other. They share their ideas and beliefs with their colleagues which intrigued the strong influence on their decision making (Zaighum, 2019, p.14). In relevance of these arguments, same trend can be supposed in terms of working capital management practices. 


\subsection{Empirical Findings and Hypothesis Development}

In literature, wide range of studies (both empirical and theoretical) discussed the working capital management and mimicking behavior separately (Yenice, 2015; Mazlan, 2018; Grennan, 2019). The objectives of these studies were to highlight the multiple issues which firms face to manage their working capital and to discuss corporate mimicking behavior in variety of business decisions. The Aksoy and Yalçine (2013, p.68) vowed that the working capital management practices highly influence from firm size. They have also found the influence of some exogenous factors such as financial sector development, inflation and tax regulations etc. on working capital management. Similarly, the study arranged by Mongrut et al., (2014) on Latin American firms intrigued the sales growth as important determinants of working capital management. Another study conducted by Doğan and Elitaş (2014) on Borsa Istanbul companies has suggested the firm specific determinants of working capital. The findings of their study argued that return on assets (ROA) and leverage has significant relationship with working capital management. They have also discussed the other determinants of WCM i.e. cash flow, interest rate and GDP etc. The results of these studies arranged in different areas confirmed the intended relationship of working capital management with other decisions made at firm level. Moreover, these studies stimulate the further studies on working capital management.

The cognitive psychology of managers which indulged in decision making is prone to be biased due to some factors (Malmendier, 2011). This biasness may be due to overconfidence (Hackbarth, 2008), emotions and moods (Kida et al., 2001) and selfserving attribution (Li, 2010) etc. Another psychological attribution of corporate managers is mimicking behavior in which they follow their peer firm's policies. The number of studies have confirmed the mimicking or herding behavior of corporations in variety of business decisions i.e. investment decision (Anwar, 2018), financing decisions (Leary, 2014), cash holding decisions (Chen, Chan, \& Chang, 2019) and tax avoidance ( $\mathrm{Li}$ et al., 2014). Furthermore, notions of signaling theory suggested that decision making of corporate managers depends upon future business movements of other colleague firms (Brigham \& Houston, 2009). Similarly, information-based theory reveals that firms shared large number of information i.e. financial statements, future 
investment policy, anticipation of business risks, current and future business engagements and contracts. This sharing behavior has deep spillover effect on thinking capacity of corporate managers (Kumar \& Langberg, 2010). All these decisions are financial nature which induces further research on working capital management which is also a financial nature. To test the peer influence, following hypothesis can be developed

$H_{1}$ : Peers has significant influence on corporate's working capital management practices.

\section{Data and Methodology}

\subsection{Discussion of Data}

In this study, non-experimental research design was adopted, and secondary data were utilized. Data of non-financial sector firms were collected from published statements by The State Bank of Pakistan. It is an authorized institution authenticated by The Government of Pakistan which carry the financial detail of whole economic sector. Study includes the Pakistani non-financial sector due to certain reasons. First, there exists more uncertainties which stimulate the empirical studies to find out the herding behavior significance. Second, as per poor governance and biases managerial personality in Pakistan (Javaid, 2010), it's necessary to give the alternate business model to manage the business operations by using the herding behavior. Moreover, as study is going to be conducted in Pakistan so it's more specific to make the analysis on Pakistan. But the findings may be used for other similar economies to manage the working capital. Further, the non-random sampling technique was followed and sample size consists of ten years data (2009-2018) of listed non-financial sector firms. To make the sample more results oreinted, the firms which have missing information for 5 or more than 5 years were purged from analysis. After applying this sampling technique, 132 listed firms were left who contribute in final analysis. Moreover, to specify the industrial classification, the SIC (standard industrial code) were used. These codes specified the industrial segmentation i.e. sic codes 100 to 999 used for agricultural sector firms, 1000 to 1499 used for mining firms and 1500 to 1999 are specified for 
those firms which comes under construction industry. The SIC codes 2000 to 3999 are for manufacturing firms, 4000 to 4999 are for transportation, communication, electricity and sanitary industry. The whole sale firms come under the SIC code 5000 to 5199 and retail business in 5200 to 5999. The firms which have SIC codes from 6000 to 6999 were excluded from sample because these are financial nature firms i.e. banks, fund management institutes and insurance companies. Finally, the firms which have SIC codes from 7000 to 8999 were classified as service industry firms.

\subsection{Methodolgy}

As for concern methodoligical discussion, the peer firm calculation was made by excluding the firm $\mathrm{I}$, from specific industry $\mathrm{j}$, for time $\mathrm{t}$ and taking the average of remaining firms. This method of peer firm calculation is in line with Leary (2014) and Anwar (2018). For the purpose of regression estimation, and econometric test named Generalized method of moments (GMM) applied due to problem of endogeniety. To proceeds further, first we have to test that either there exists the problem of endogeniety or not? To test whether there exists endogeniety problem, we have develop hypotheses and employed the Correlated Random Huasman test to test these these hypotheses.

H1: There exists the problem of endogeniety.

Ho: There does not exist the problem of endogeniety.

Table 1 Correlated Random Effect-Huasman Test

\begin{tabular}{llll}
\hline Test summary & Chi-sq.statistic & Chi-sq. D.F & Probability \\
\hline Cross-section & 18.0405 & 10 & 0.0543 \\
random & & & \\
\hline
\end{tabular}

The probability value of chi-square is 0.05 which is equal to bench mark $\mathrm{P} \leq 0.05$ which reject the null hypothesis and accept the alternate hypothesis. Alternate hypothesis vows that there exist the potential problem of endogeniety. To adress this problem, implication of GMM is imperative because it has ability to adress the problem of potential endogeniety which may arises due to hetergenous sample selection. Moreover, as the data are both firm specific and macro-economic, therefore there are more chances 
that predicator variable correlates with error terms which unfit the implication of ordinary least square test (OLS) to estimate the regression. GMM model is an econometric trick that includes both OLS and 2SLS (two stage least square).

\subsection{Variables Description}

The well-known proxy of working capital management (WCM) which used as explained variable is cash conversion cycle (CCC). The CCC splits into three ratios i.e. number of days account receivable, number of days inventory and number of account payable which depict the overall operational efficiency of firms from purchase of raw material to finished goods payment. These are common proxies which have extensively used in past studies for CCC quantification (Karaduman et al., 2011; Sharma \& Kumar, 2011; Enqvist et al., 2014). The CCC play the role of best fitted indicator of firm future cash flow which stated the working capital management (Kamath, 1989). Furthermore, previous studies have aslo suggested the CCC as indicator of firm working capital management (Deelof, 2003; Ukaegbu, 2014). The general formula of CCC is as

$$
\begin{aligned}
& \text { CCC } \\
& =(\text { No. of Days Account Receivable + No. of Days Account Inventory }) \\
& -(\text { No. of Days Account Payable })
\end{aligned}
$$

Where

No. of Days Account Receivable

$$
=\left(\frac{\text { Account Receivable }}{\text { Sales }}\right) \times 365
$$

No. of Days Account Payable

$$
=\left(\frac{\text { Account Payable }}{\text { Cost of Goods Sold }}\right) \times 365
$$

No. of Days Inventory

$$
=\left(\frac{\text { Inventory }}{\text { Cost of Goods Sold }}\right) \times 365
$$


The literature is saturated with numerous determinants which effects the corporate working capital management. Some of factors are leverage, profitability, and firm size at corporate level and financial sector development, inflation rate and GDP growth rate at macro level (Nyeadi, Sare, \& Aawaar, 2018). These factors were used as additional variables (control variables) which may affect the working capital management decision. Gearing or leverage is measured as total debt to asset ratio. The study arranged by Abbadi and Abbadi (2012) argued that the more leveraged firms try to keep their working capital at small level. These firms manage their current assets with fewer loans because they are already in stress. Its anticipated relationship is negative. Next, firm profitability (ROA) was measured as earnings before interest and tax (EBIT) divided by total assets. The firm profitability has controversial relationship with working capital management. According to pecking order theory (Myers, 1984), working capital has inverse relationship because more profitable firms invest more in high earning projects. But in contrast, the study of Onaolapo and Kajola (2015) argued the positive relationship because more profitable firms pay more intentions on working capital management and have more current assets. Another firm specific determinant is firm size measured as log of total sales.

At macro-economic level, the financial sector development index, inflation rate and GDP growth rate were used as control variable and their exogenous effect is analyzed on working capital management. The measurement of financial sector development index and inflation is extracted from developed index of International Monetary Fund $(I M F)^{2}$. IMF defined the inflation rate as it is the rate of increase in the prices of consumable goods during a specific time period. It also referred to as decrease in the value of money. Similarly, financial sector development index is a systematic measurement of current condition of financial sector of any country in which its development status judged on different parameters i.e. depth, success and efficiency. According to The World Bank, GDP is the monetary value of all finished goods and services that is produced by a specific economy during a specific time period and GDP growth rate is the percentage of growth with comparison of previous year.

\footnotetext{
${ }^{2}$ https://data.imf.org/?sk=F8032E80-B36C-43B1-AC26-493C5B1CD33B
} 


\subsection{Econometric Models}

\section{Base line model}

$$
\begin{aligned}
& W C M_{i j t} \\
& =\beta_{\circ}+\beta_{1} P_{W C M_{-i j}+\beta_{2} \text { Corporate specific factors }_{-i j t}} \\
& +\beta_{3} \text { Peer specific factor } \text { fijt- }+\beta_{4} F S D_{t}+\beta_{5} I N F_{t}+\beta_{6} G D P_{t} \\
& +\varepsilon_{i j t}
\end{aligned}
$$

The econometric equation no. 1 shows the relationship between corporate working capital $\left(\mathrm{WCM}_{\mathrm{ijt}}\right)$ and peer working capital management (PWCM-ijt). The indices ijt are vectors that represents the firm $\mathrm{i}$, industry $\mathrm{j}$, and time period t. Corporate specific

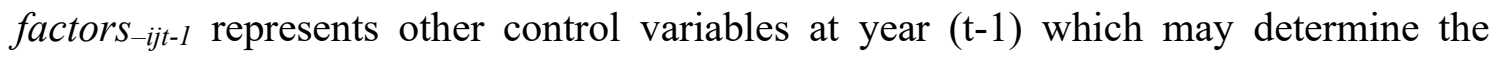
working capital management decisions. The Peer specific factor-ijt-1 indicates the peer specific control variables. The $F S D_{t}$ is financial sector development, INFt is inflation rate and GDPt is for gross domestic product growth rate. The sign of eijt is for error term at firm level that is assumed to be heteroskedastic. Equation 1 shows the reduced form of model.

\section{Corporate working capital management model}

$W C M_{i j t}=\beta_{\circ}+\beta_{1} L V G_{t-1}+\beta_{2} R O A_{t-1}+\beta_{3} F S_{t-1}+\beta_{4} F S D_{t}+\beta_{5} I N F_{t}+\beta_{6} G D P_{t}+$ $\varepsilon_{i j t}$

Equation 2 represents the corporate working capital and its relevant determinants. The $W C M_{i j t}$ is working capital of firm $\mathrm{i}$, from industry $\mathrm{j}$ and at time $\mathrm{t}, L V G_{t-1}$ is previous year leverage, $R O A_{t-1}$ depicts the last year profitability and $F S_{t-1}$ is denoted for last year firm size. Macro-economic determinants are financial sector development $\left(\mathrm{FSD}_{\mathrm{t}}\right)$, inflation $\left(\mathrm{INF}_{\mathrm{t}}\right)$ and gross domestic product growth rate $\left(\mathrm{GDP}_{\mathrm{t}}\right)$. Vector $t$ represents that these factors only change with specific to time but not to country or cross-section as analysis consists of only Pakistan.

\section{Peer working capital management model}




$$
\begin{aligned}
W C M_{-i j t}=\beta_{\circ} & +\beta_{1} L V G_{-i j t-}+\beta_{2} R O A_{-i j t-1}+\beta_{3} F S_{-i j t-1}+\beta_{4} F S D_{t}+\beta_{5} I N F_{t} \\
& +\beta_{6} G D P_{t}+\varepsilon_{i j t}
\end{aligned}
$$

Equation 3 exemplifies the same determinants which have shown in equation 2 but at peer level.

\begin{tabular}{|c|c|c|c|}
\hline Sr no. & Proxy variable & Calculation & Predicted sign \\
\hline 1 & WCM & Cash conversion cycle (CCC) & Positive/negative \\
\hline 2 & LVG & Total debt to total assets ratio & Negative \\
\hline 3 & $\mathrm{ROA}$ & $\begin{array}{l}\text { Earnings before interest and tax to total assets } \\
\text { ratio }\end{array}$ & Positive \\
\hline 4 & FS & Log of total assets & Positive \\
\hline 5 & FSD & $\begin{array}{l}\text { IMF has developed a country wise index on } \\
\text { three parameters i.e. depth, access and } \\
\text { efficiency. These parameters summarize that } \\
\text { how financial sector of a specific country } \\
\text { performs on depth (liquidity and size), access } \\
\text { (ability of individual or companies to approach } \\
\text { the financial services) and efficiency (ability to } \\
\text { offer the financial services at lowest cost) }\end{array}$ & Negative \\
\hline 6 & INF & $\begin{array}{l}\text { Inflation (INF) is measured as an increment rate } \\
\text { in the value of consumable goods. }\end{array}$ & Negative \\
\hline 7 & GDP & $\begin{array}{l}\text { An increase in the value of all goods and } \\
\text { services produced by an economy during a } \\
\text { specific time period. }\end{array}$ & Positive \\
\hline
\end{tabular}

Table 2 Variable Calculation and Predicted Sign

Note: $\mathrm{WCM}=$ working capital management, Leverage, ROA: profitability, FS: firm size, FSD: financial sector development, INF: inflation, GDP: GDP growth rate Description: Based on detail literature review as mentioned above (in literature review section), table 2 presents all variables of study, their specific calculation and predicted signs which have empirically suggested by previous studies. Most of the predicted signs have specified in other economies due to which actual findings may or may not deviate from predicted signs in Pakistani non-financial sector data set. 


\section{Results and Discussion}

Table 3 Descriptive Statistics

\begin{tabular}{|c|c|c|c|c|c|}
\hline & Mean & Median & Std. Deviation & Skewness & Kurtosis \\
\hline $\mathrm{CCC}$ & 72.317 & 69.831 & 0.1222 & 1.259 & 4.757 \\
\hline СССР & 70.642 & 77.331 & 0.364 & -1.020 & 4.234 \\
\hline \multicolumn{6}{|c|}{ Corporate Firm Specific Factors } \\
\hline LVG & 0.341 & 0.331 & 0.197 & 0.235 & 2.381 \\
\hline ROA & 0.101 & 0.094 & 0.103 & 1.081 & 10.897 \\
\hline FS & 1.975 & 1.890 & 0.061 & 0.529 & 3.321 \\
\hline \multicolumn{6}{|c|}{ Peer Firm Specific Factors } \\
\hline PLVG & 0.396 & 0.296 & 0.085 & 0.542 & 4.330 \\
\hline PROA & 0.197 & 0.100 & 0.083 & 0.862 & 4.897 \\
\hline PFS & 2.083 & 1.944 & 0.895 & 0.720 & 5.338 \\
\hline \multicolumn{6}{|c|}{ Macro-economic Factors } \\
\hline FSD & 0.243 & 0.238 & 0.063 & 0.922 & 2.778 \\
\hline INF & 9.949 & 9.682 & 0.067 & 0.495 & 2.613 \\
\hline GDP & 3.631 & 3.507 & 1.320 & -0.267 & 1.667 \\
\hline
\end{tabular}

Note: CCC: cash conversion cycle, CCCP: cash conversion cycle of peers LVG: Leverage, ROA: profitability, FS: firm size, PLVG: peer leverage, PROA: peer profitability, PFS: peer firm size, FSD: financial sector development, INF: inflation, GDP: GDP growth rate

Table 3 describes the descriptive statistics of variables used in analysis. Cash conversion cycle (CCC) expresses the time period taken by company to convert its investment in inventory to cash flow. It has mean value 72.317 (in days) which is considerably higher from CCC of peer (70.642). It suggests that corporate firm deferral their CCC with respect to their peers and have less capacity to hasten their cash flow. Furthermore, the low value of CCC for peer firms depicts the more efficient behavior of peer firms. Next, median value of CCC is 69.831 which pretends the normal trend of corporate firm's CCC and stand deviation is 0.122 or $12.2 \%$ which shows the degree of dispersion from mean value. Skewness and Kurtosis which indicate the data pattern are 1.259 and 4.757. These statistics show that data are positively skewed but normally distributed. The mean value of leverage ( $L V G)$ for corporate firms is 0.341 but for peer firm, it is 0.396. Peer firms acquired more loans to finance its assets as compared to corporate firms. Similarly, ROA for corporate firms is 0.101 which is less than ROA of peers (0.197). Peer firms have more capacity to earn more profit by utilizing their assets. As moving forward, the size of corporate firms (FS) is1.975 but size of peer firms (PFS) is 2.083. Regarding the macro-economic variables, FSD, INF and GDP 
have mean values as $0.243,9.949$ and 3.631 relatively. These statistics depict the macro-economic condition in Pakistan.

Table 4 Correlation Analysis

\begin{tabular}{|c|c|c|c|c|c|c|c|c|c|c|c|}
\hline & $\mathrm{CCC}$ & CCCP & LVG & ROA & FS & PLVG & PROA & PFS & FSD & INF & GDP \\
\hline $\mathbf{C C C}$ & 1.000 & & & & & & & & & & \\
\hline СССР & 0.699 & 1.000 & & & & & & & & & \\
\hline LVG & -0.034 & -0.054 & 1.000 & & & & & & & & \\
\hline ROA & 0.051 & 0.065 & -0.349 & 1.000 & & & & & & & \\
\hline FS & 0.101 & -0.023 & -0.148 & 0.165 & 1.000 & & & & & & \\
\hline PLVG & -0.044 & 0.009 & 0.004 & 0.041 & -0.041 & 1.000 & & & & & \\
\hline PROA & -0.036 & 0.028 & -0.006 & 0.040 & -0.038 & 0.997 & 1.000 & & & & \\
\hline PFS & -0.044 & -0.026 & -0.042 & 0.001 & 0.126 & 0.928 & 0.933 & 1.000 & & & \\
\hline FSD & -0.214 & -0.703 & 0.089 & -0.046 & -0.108 & 0.018 & -0.006 & -0.051 & 1.000 & & \\
\hline INF & -0.097 & -0.224 & 0.085 & -0.024 & -0.089 & 0.020 & -0.005 & -0.044 & 0.250 & 1.000 & \\
\hline GDP & 0.039 & 0.009 & -0.059 & 0.012 & 0.064 & -0.016 & 0.003 & 0.035 & -0.051 & -0.911 & 1.000 \\
\hline
\end{tabular}

Note: CCC: cash conversion cycle, CCCP: cash conversion cycle of peers LVG:

Leverage, ROA: profitability, FS: firm size, PLVG: peer leverage, PROA: peer profitability, PFS: peer firm size, FSD: financial sector development, INF: inflation, GDP: GDP growth rate

Table 4 shows the correlation analysis of variables of study. In column 2, the detail of corporate cash conversion cycle (CCC) has depicted with other variables of study. The correlation coefficient of CCCP (cash conversion cycle for peers) is 0.699 which suggests the degree of association or correlation between CCC and CCCP. Corporate firms strongly adhere with their peers to manage their working capital. As for as corporate specific factors concerned i.e. Leverage (LVG), profitability (ROA) and firm size (FS), they have $-0.034,0.051$ and 0.101 correlation coefficient values with CCC. These values show the direction and degree of participation in determining the CCC. Similarly, peer specific factors prevail the specific values which indicate the strength of participation. Their correlation coefficient values are $-0.044,-0.036$, and -0.044 respectively. The financial sector development (FSD) has correlation coefficient value as -0.214 which shows that financial development negatively affects the corporate working capital management practices. Similarly, inflation (INF) is negatively correlated (-0.097) with CCC but GDP has positive correlation coefficient value (0.039). Column 3 specifies the correlations coefficients for peer firms CCC. Cash conversion cycle (CCC) of peer firms have more strong responsive behavior towards leverage (LVG) and profitability (ROA) as compared to corporate firms. The 
correlation coefficients of LVG and ROA are -0.054 and 0.065 which are greater than corporate CCC. Similarly, FSD and INF have more strong effect on peer CCC as compared to corporate CCC. However, some determinants have weaker effect (such as FS and GDP etc.) on peer CCC. The correlation coefficients of other variables carry the corresponding values and depict the specific nature of relationship (either positive or negative) with strength of association. Most of the variables have normal corresponding correlation coefficient values which disagreed with the presence of multicollinearity problem.

Table 5 Relationship Between Peer and Corporate Working Capital Management

\begin{tabular}{lll}
\hline & Coefficient & T-value \\
\hline PCCC & 0.313 & $2.191^{* * *}$ \\
Firm-Specific Variables & & \\
LVG & -54.935 & $-1.821^{* *}$ \\
ROA & 0.725 & $2.258^{* * *}$ \\
FS & 134.141 & $4.895^{* * *}$ \\
Peer-Specific Variables & & \\
PLVG & -188.707 & $-1.754^{* *}$ \\
PROA & -265.556 & -1.338 \\
PFS & -147.965 & $-1.730^{* *}$ \\
Macro-economic Variables & & \\
FSD & -316.464 & $-2.835^{* * *}$ \\
INF & -0.184 & $-1.812^{* *}$ \\
GDP & 6.030 & $1.891^{* *}$ \\
Adj. R-squared & 0.688 & \\
D.W Stat & 2.014 & \\
J-statistic & 579.000 & \\
Prob. Of J-statistic & 0.16 & \\
\hline
\end{tabular}

Note: CCC: cash conversion cycle, CCCP: cash conversion cycle of peers LVG: Leverage, ROA: profitability, FS: firm size, PLVG: peer leverage, PROA: peer profitability, PFS: peer firm size, FSD: financial sector development, INF: inflation, GDP: GDP growth rate Furthermore: significance at a 10\% level (two-tailed test), ** significance at a 5\% level (two-tailed test), and *** significance at a $1 \%$ level (twotailed test)

Table 5 reveals the overall regression analysis between corporate and peer working capital management practices. It also includes the other variables which may determine the corporate working capital management decision. The t-value of PCCC which 
proxied the peer working capital management (WCM) practices is 2.191 which confirm the effect of peer firm on corporate firm. The coefficient of peer firm is 0.313 which is significant at $1 \%$ level and positively associated with corporate CCC. According to social learning theory, corporate firms learn the business practices from their peers and working capital management is one from these practices. These findings of study are consistent with empirical findings of previous studies in which they have confirmed the adherence of corporate firms with their peer' s business decisions (Leary, 2014; Chen, 2017; Chen et al., 2019). More specific, the study of Anwar and Akhtar (2018) has empirically documented that Pakistan non-financial sector firms adhere with their peer investment policy. This study empirically adds new thought in relevance of peer effect in case of WCM in existing literature. Focusing on corporate specific factors, leverage (LVG) has negative but profitability (ROA) has positive and significant impact on corporate WCM. Their t-values are -1.821 and 2.258 which are significant at $5 \%$ and $1 \%$ relatively. Firms which acquire more loans to finance the assets have more attentions towards tied up their funds in account receivable and inventory which delayed their CCC (Nazir \& Afza, 2009). Pecking order theory also suggested the negative impact of leverage (LVG) on working capital management. But more profitable firms pay more attention towards WCM and have short CCC (Afza \& Nazir, 2008). Firm size (FS) is positively and significantly (4.895) related with CCC. Bigger firms follow the aggressive financial policies which alternatively tends to more efficient working capital management practices (Mahmood et al., 2019).

Now, concerning upon peer specific factors, peer leverage (PLVG) has negative and significant t-value (-1.754). It has same association with WCM as for corporate firm leverage. But contrary to corporate firm size, the peer firm size (PFS) has negative and signifcant (-1.730) impact on CCC. The negative impact depicts that larger peer firms have more control over their suppliers which allow them to delay their payables and causes the longer CCC (Abbadi, 2012). To inspect the macro-economic effect, this study included the three macro-economic variables i.e. FSD, INF and GDP. The tvalues of financial sector development (FSD) and inflation rate (INF) show the negative but significant impact on WCM. FSD is significant at $1 \%$ but INF is significant at $5 \%$ level. High financial development attracts the corporate managers to invest more in 
banking securities instead of physical investment in inventory. It reduces the intention of corporate managers on WCM practices which causes the negative impact. Similarly during the high inflation period, both suppliers and borrowers experienced rise in cost of capital. It discourages the supplier willingness to supply the inventoy and producer ability to convert the inventory into cash. It causes the longer CCC due to tied up of inventory (Ali, Ramzan \& Khan, 2011; Mathuva, 2014). But gross domestic product (GDP) growth rate has positive and signficant t-stat value as 1.891. High GDP growth rate promotes the business activities in a country due to which the production capacity of business increases which alternatively speed up the cash conversion cycle (Mohamad \& Elias, 2013). The significant impact of macro-economic factors indicate the role of economic condition and policies in determining the business efficiency. Overall results reveal the significant impact of peer WCM practices on corporate firms. It also results in acceptance of alternate hyphothesis $\left(\mathrm{H}_{1}\right)$.

\section{Conclusion}

The efficient management of working capital is necessary as it determines the higher return for stake holders. When corporate managers unable to manage the working capital then it rendered its long-term adverse effects in the form of low investment, high liquidity position and high inventory carrying cost. Literature discusses the different factor of working capital management. But discussion on peer effect does not exist specifically for working capital management practices. Literature has also evidenced the peer influence in number of financial and non-financial decisions. The present study discusses peer influence on corporate working capital management practices by including the both macro-economic and firm specific factors. Firm specific factors are leverage, ROA and firm size while financial development, inflation rate and GDP growth rate are macro-economic factors. Cash conversion cycle use as proxy of working capital management at corporate and peer level. The empirical findings suggest the significant relationship between corporate and peer WCM practices. The analysis also reveals the effect of other variables on working capital management which is in accordance with previous studies findings. 
Findings have important practical implications for corporate manager to consider the peer effect in WCM practices. They can follow their peers as results suggests the positive influence of peer firms on corporate firms. Analysis also reveals the dynamic role of country economic condition in firm level financial decisions. However, current analysis is limited by not including the individual effect of different industries as Afza and Tahir (2008) has revealed the significant impact of industrial categorization on working capital management. Each industry has specific setting of WCM. In future, comprehensive studies can be arranged which explore the peer influence in different types of industries.

\section{References}

Abbadi, S. M. (2012). The Determinants of Working Capital requirements in Palestinian Industrial Corporations. International Journal of Economics and Finance, 5(1), 65-75.

Afza, T. , \& Adnan, S.M. (2007). Determinants of Corporate Cash holdings: A Case Study of Pakistan. Proceedings of Singapore Economic Review Conference (SERC) 2007, Singapore. Singapore Economics Review and The University of Manchester.

Afza, T., \& Nazir, M. S. (2008). Working Capital Management Policies of Firms: Empirical Evidence from Pakistan. Pakistan Journal of Commerce and Social Sciences, 1(1), 2536.

Aksoy, A., \& Yalçiner, K. (2013). Working capital management. Ankara: Detay Yayınc1lı.

Ali, S., Ramzan, M., \& Khan, A. (2011). Searching for Internal and External factors that determine Working Capital Management for Manufacturing Firms in Pakistan. African Journal of Business Management, 5(7), 2942-2949.

Anwar , M. M., \& Akhtar, M. R. (2018). Do Peer Firms Impact Corporate Investment Policies? Pakistan Journal of Commerce and Social Sciences, 12(1), 363-378.

Brigham, E. F. (2009). Fundamentals of Financial Management. Mason: Cengage Learning. 
Charitou, M. S. (2010). The Effect Of Working Capital Management On Firms Profitability: Empirical Evidence From An Emerging Market. Journal of Business \& Economics Research, 8(12), 63-68. doi:https://doi.org/10.19030/jber.v8i12.782

Chen, S., \& Hui, M. (2017). Peer Effect in decision-making: Evidence from Corporate Investment. China Journal of Accounting Research, 10(2), 167-188.

Chen, Y. W., Chan, K., \& Chang, Y. (2019). Peer Effects on Corporate Cash Holdings. International Review of Economics \& Finance, 61, 213-227.

Chevalier, J. A. (1996). Capital-market imperfections and countercyclical markups: Theory and evidence. The American Economic Review, 86(4), 703-725.

Deelof, M. (2003). Does Working Capital Management Affect Profitability of Belgian Firms? Journal of Business Finance and Accounting, 30(3-4), 573-588.

Doğan, M., \& Elitaş, B. L. (2014). The Determinants of Working Capital requirement: An examination on Borsa Istanbul Food Sector. World of Accounting Science, 16(2).

Enqvist, J., Graham, M., \& Nikkinen, J. (2014). The Impact of Working Capital Management on Firm Profitability in Different Business Cycles: Evidence from Finland. Research in International Business and Finance, 32, 36-49.

Farooq, U. (2019). Impact of Inventory Turnover on Profitability of Non- Financial Sector Firms in Pakistan. Journal of Finance and Accounting Research, 1(1), 34-51.

Ganesan, V. (2007). An Analysis of Working Capital Management Efficiency in Telecommunication Equipment Industry. River Academic Journal, 3(2), 1-10.

Gill, A. S., \& Biger, N. (2013). The Impact of Corporate Governance on Working Capital Management Efficiency of American Manufacturing Frms. Managerial Finance, 39(2), 116-132.

Gill, A., Biger, N., \& Mathur, N. (2010). The Relationship Between Working Capital Management And Profitability: Evidence From The United States. Economics and Finance Journal, 2, 1-9. 
Graham, J. R. (2001). The Theory and Practice of Corporate Finance: Evidence from the Field. Journal of Financial Economics, 60(2-3), 187-243.

Grennan, J. P. (2019). Dividend Payments as a Response to Peer Influence. Journal of Financial Economics, 131(3), 549-570.

Hackbarth, D. (2008). Managerial Traits and Capital Structure Decisions. Journal of Financial and Quantitative Analysis, 43(4), 843-882.

Javaid, U. (2010). Corruption and its Deep Impact on Good Goverance in Pakistan. Pakistan Economic and Social Review, 48(1), 123-134.

Kamath, R. (1989). How useful are Common Liquidity Measures? Journal of Cash Management, 9(1), 24-28.

Karaduman, H. A. (2011). The Relationship Between Working Capital Management and Profitability: Evidence from an Emerging Market. International Research Journal of Finance and Economics, 66, 61-67.

Kaur, J. (2010). Working Capital Management in Indian tyre Industry. International Research Journal of Finance and Economics, 46, 7-31.

Kida, T. E. (2001). The Influence of Affect on Managers'Capital-Budgeting Decisions. Contemporary Accounting Research, 18(3), 477-494.

Kieschnick, R. M. (2013). Working Capital Management and Shareholders' Wealth. Review of Finance, 17(5), 1827-1852.

Kim, J., , Kim, H., \& Woods, D. (2011). Determinants of Corporate cash-holding levels: An Empirical Examination of the Restaurant Industry. International Journal of Hospitality Management, 30(3), 568-574.

Knauer, T., \& Wöhrmann, A. (2013). Working Capital Management and Firm Profitability. Journal of Management Control, 24(1), 77-87.

Kumar, P., \& Langberg, N. (2010). Innovation and Investment Bubbles. Working Paper. 
Kwenda, F., \& Holden, M. (2014). Determinants of Working Capital Investment in South Africa: Evidence from selected JSE-listed Firms. Journal of Economics and Behavioral Studies, 6(7), 569-580.

Leary, M. T., \& Roberts, M. R. (2014). Do Peer Firms Affect Corporate Financial Policy? The Journal of Finance, 69(1), 139-177.

Li, F. (2010). Managers' Self-Serving Attribution Bias and Corporate Financial Policies. doi: SSRN http://ssrn.com/abstract=1639005

Li, L., Winkelman, A., K., \& D'Amico, J. R. (2014). Peer Pressure on Tax Avoidance: A Special Perspective from Firms' Fiscal Year-Ends. Journal of Accounting \& Finance, $14(6), 171-188$.

Liu, X., \& Chen, J. J. (2012). The Effect of Inter-Organizational Learning on the Growth of Industry Cluster. Science Research Management, 33(1), 28-35.

Mahmood, F., Han, D., Ali, N., Mubeen, R., \& Shahzad, U. (2019). Moderating Effects of Firm Size and Leverage on the Working Capital Finance-Profitability Relationship: Evidence from China. Sustainability, 11, 1-14.

Malmendier ulrike, G. t. (2011). Overconfidence and Early-Life Experiences: The Effect of Managerial Traits on Corporate Financial Policies. The journal of finance, 66(5), 16871733.

Maquieira, C. P.-A. (2012). Theory and Practice of Corporate Finance: Evidence and Distinctive Features in Latin America. Emerging Markets Review, 13(2), 118-148.

Mathuva, D. M. (2014). An empirical analysis of the determinants of the cash conversion cycle in Kenyan listed non-financial firms. Journal of Accounting in Emerging Economies, $4(2), 175-196$.

Mazlan, A. R., \& Leng, C. Y. (2018). The Moderating Effect of Working Capital Management on the Relationship between Working Capital Determinants and Firm Performance. Indian-Pacific Journal of Accounting and Finance, 2(1), 38-48. 
Mohamad, N. A., \& Elias, S. B. (2013). An Assessment on Determinant of Working Capital Management from Malaysian Public Listed Companies. International Journal of Academic Research in Accounting, Finance and Management Sciences, 3(4), 224-228.

Mongrut, S. F. (2014). Determinants of Working Capital Management in Latin American Companies. Innovar, 24(51), 5-18. doi:

Myers, M. (1984). The Corporate Financing and Investment Decision, When Firms have Information that Investors do not have. Journal of Finance and Economic, 13(2), 187221.

Nazir, M. S., \& Afza, T. (2009). Working Capital Requirements and the Determining Factors in Pakistan. The Icfai Journal of Applied finance, 15(4), 28-37.

Nyeadi, J. D., Sare, A. Y., \& Aawaar, G. (2018). Determinants of Working Capital Requirement in listed Firms: Empirical evidence Using a Dynamic System GMM. Cogent Economics \& Finance, 6, 1-14.

Onaolapo, A. \&. (2015). What are the Determinants of Working Capital Requirements of Nigerian firms? Research Journal of FinanceandAccounting, 6(6), 1-18.

Padachi, K. (2006). Trends in Working Capital Management and its Impact on Firm's Performance: An analysis of Mauritian small Manufacturing Firms. International Review of Business Research Papers, 2(2), 45-58.

Rehman, A., \& Nasir, M. (2007). Working capital management and profitability-case of Pakistani firms. International Review of Business Research Papers, 3(1), 279-300.

Sharma, A., \& Kumar, S. (2011). Effect of Working Capital Management on Firm Profitability: Empirical Evidence from India. Global Business Review, 12(1), 159-173.

Shue, K. (2013). Executive Networks and Firm Policies: Evidence from the Random Assignment of MBA Peers. The Review of Financial Studies, 26(6), 1401-1442.

Singh, H. P., \& Kumar, S. (2014). Working Capital Management: A Literature Review and Research Agenda. Qualitative Research in Financial Markets, 6(2), 173-197. 
Ukaegbu, B. (2014). The Significance of Working Capital Management in Determining the Firm Profitability: Evidence from the Developing Economies in Africa. Rsearch in International Business and Finance, 31(May), 1-16.

Yenice, S. (2015). Determining the Influences of Macroeconomic Variables on Working Capital through Artificial Neural Network Modeling: The Case of Turkey. International Business Research, 8(8), 14-26.

Zaighum, I. \&. (2019). Peer Effects, Financial Decisions, and Industry Concentration: A Review. SEISENSE Journal of Management, 2(2), 13-21.

Zubairi, H. (2011). Impact of Working Capital Management and Capital Structure on the Profitability of Auto-mobile Firms in Pakistan. In Finance and Corporate Governance Conference.

\section{Highlights}

Subject: Do Peer Influence Corporate Firms? Evidence from Working Capital Management Practices

- Peer has significant impact on corporate working capital management practices (WCM).

- At corporate level, leverage has negative while firm size and profitability have positive and significant effect.

- At peer level, leverage and firm size have negative and significant effect on WCM.

- At macro-economic level, inflation and financial sector development have negative while gross domestic product (GDP) has positive and significant impact on WCM.

- For regression estimation, generalized method of moments (GMM) was used. 